\title{
Sistem Pendukung Keputusan Menentukan Tingkat Resiko Penjualan Online Dengan Menggunakan Metode TOPSIS
}

\author{
Yosapat Sembiring ${ }^{1 *}$, Paska Marto Hasugian² \\ ${ }^{1,2}$ STMIK Pelita Nusantara \\ Jl. Iskandar Muda No. 1 Medan 20154 Indonesia \\ Corresponding author : sembiring.orc33@gmail.com
}

\begin{abstract}
Abstrak - Pada saat ini sudah banyak orang yang mulai melakukan penjualan secara online. Meskipun hanya bermodalkan barang yang seadanya untuk melakukan penjualan online tidak sedikit orang yang berhasil melakukan penjualan online ini. Metode TOPSIS adalah salah satu metode pengambilan keputusan multikriteria, metode ini merupakan salah satu yang banyak digunakan untuk menyelesaikan pengambilan keputusan secara praktis. Semakin banyaknya faktor yang harus dipertimbangkan dalam proses pengambilan keputusan, maka semakin relatif sulit juga untuk mengambil keputusan terhadap suatu permasalahan. identifikasi masalah penelitian adalah penerapan SPK dalam menentukan tingkat resiko penjualan online. Sistem ini dibangun dengan menggunakan bahasa pemrograman PHP dengan pengelolaan data menggunakan database Mysql. Hasil perangkingan 1. Mebel = 0,8062 2.Elektronik =0,5810 3. Fashion =0,1230

Kata kunci: alternative, SPK, metode TOPSIS, multi kriteria, perangkingan
\end{abstract}

Abstract - At this time many people have started selling online. Even though only with makeshift items to make online sales, not a few people have succeeded in making these online sales. The TOPSIS method is one of the multicriteria decision-making methods, this method is one that is widely used to complete practical decision making. The more factors that must be considered in the decision making process, the more difficult it will be to make a decision on an issue. identification of research problems is the application of the DSS in determining the level of risk of online sales. This system was built using the PHP programming language with data management using the MySQL database. Rank results 1. Furniture $=0.8062$ 2. Electronics $=0.58103$. Fashion $=0.1230$

Keywords: alternative, DSS, TOPSIS method, multi criteria, ranking

\section{Pendahuluan}

Sistem pendukung keputusan (SPK) merupakan adalah bagian dari sistem informasi berbasis komputer yang dipakai untuk mendukungpengambilan keputusan dalam suatu organisasi atau perusahaan. Dapat juga dikatakan sebagai sistem komputer yang mengolah data menjadi informasi untuk mengambil keputusan dari masalah semi-terstruktur yang spesifik. Sistem pendukung keputusan memiliki beberapa metode untuk mendapatkan suatu keputusan yang dapat digunakan untuk menyelesaikan masalah yang berkaitan dengan layanan penjualan online untuk mengukur tingkat resiko penjualan online. Penjualan online bukanlah hal yang baru di dalam kehidupan kita sehari-hari[1]. Pada saat ini sudah banyak orang yang mulai melakukan penjualan secara online. Meskipun hanya bermodalkan barang yang seadanya untuk melakukan penjualan online tidak sedikit orang yang berhasil melakukan penjualan online ini. Bahkan sudah banyak situs jual beli yang menyediakan tempat untuk melakukan penjualan online.

Meskipun penjualan online merupakan hal yang kelihatan mudah, banyak Permalasahan atau resiko yang harus dihadapi untuk memulai prnjualan secara online. Mulai dari pemilihan produk apa yang akan di bisniskan, target pasar yang menjadi sasaran pemasaran produk yang akan dijual, Tingkat keamanan penjualan, strategi dan langkah konkret yang akan di laksanakan untuk mampu bersaing dengan produk lain di pasaran, menciptakan kolaborasasi atau kerjasama dengan pihak supplier produk dan agen-agen pemasaran produk di pasaran sampai manajemen untuk membuat bisnis tersebut tetap berjalan, selain itu, barang atau produk yang di jual kurang laku. Itulah beberapa masalah yang membuat orang-orang berpikir ulang untuk membuka Penjualan secara online. Oleh karena itu di gunakan metodeTOPSIS untuk mendapatkan suatu keputusan [2].

Jika upaya pengambilan keputusan dari suatu permasalahan tertentu, selain mempertimbangkan berbagai faktor/kriteria yang beragam, juga melibatkan beberapa orang pengambil keputusan. Permasalahan yang demikian dikenal dengan permasalahan multiple criteria decision making (MCDM) [3]. Dengan kata lain, MCDM juga dapat disebut sebagai suatu pengambilan keputusan untuk memilih alternatif terbaik dari sejumlah alternatif berdasarkan beberapa kriteria tertentu. Metode TOPSIS digunakan sebagai suatu upaya untuk menyelesaikan permasalahan multiple criteria decision making. Hal ini disebabkan konsepnya sederhana dan mudah dipahami. 
Penelitian SPK Penilaian Hasil Belajar Siswa Menggunakan Metode TOPSIS menjelaskan dalam proses pembelajaran siswa memperoleh penilaian. Guru berperan mengakumulasi nilai-nilai siswa dari setiap tugas yang diberikan. Hasil penilaian sering kurang objektif dan tidak transparan. Pengukuran terhadap proses dan hasil belajar yang berupa angka-angka yang mencerminkan capaian, proses dan hasil belajar. Diperlukan sistem penilaian berbasis teknologi yang mendukung mengambil keputusan menentukan hasil nilai siswa. Hal-hal yang mempengaruhi penilaian belajar siswa dikategorikan sebagai kriteria penilaian. Setiap kriteria diberikan bobot (\%). Sistem keputusan yang mendukung penilaian dalam penelitian ini menggunakan metode Technique for Order Preference by Similarity to Ideal Solution (TOPSIS), bobot dari setiap nilai kriteria membentuk matrik, dinormalisasi untuk memperoleh skor penilaian tertinggi [4].

Penelitian Penilaian Guru Terbaik SMP Tri Sakti Lubuk Pakam Menggunakan Metode Topsis, menjelaskan aplikasi SPK menggunakan data, memberikan antarmuka pengguna yang mudah, dan dapat menggabungkan pemikiran pengambil keputusan. Konsep SPK merupakan sebuah sistem interaktif berbasis komputer yang membantu pembuatan keputusan memanfaatkan data dan model untuk menyelesaikan masalah-masalah yang bersifat tidak terstruktur dan semi terstruktur [5].

\section{Tinjauan Pustaka}

\subsection{Sistem Pendukung Keputusan (SPK)}

Sistem Pendukung Keputusan (SPK) adalah sistem berbasis model yangterdiri dari prosedur-prosedur dalam pemrosesan data dan pertimbangan untukmembantu manajer dalam mengambil keputusan [6]. Sistem pendukung keputusan merupakan sistem informasi yangmenyediakan informasi, pemodelan dan pemanipulasian data yang mampu untukmendukung analisis data secara ad hoc dan pemodelan keputusan sertaberorientasi pada perencanaan masa depan. Sistem Pendukung Keputusan adalah sistem penghasil informasi spesifikyang ditujukan untuk memecahkan suatu masalah tertentu yang harus dipecahkanoleh manager pada berbagai tingkatan [7]. Dengan kata lain Sistem PendukungKeputusan adalah suatu sistem informasi berbasis komputer yang menghasilkanberbagai alternatif keputusan untuk membantu manajemen dalam menanganiberbagai permasalahan yang terstruktur dengan menggunakan data dan model. Sistem pendukung keputusan merupakan suatu sistem komputer yangberisi 3 komponen interaksi, yaitu: sistem bahasa (mekanisme komunikasi antarapengguna dengan komponen lain dalam DSS), sistem pengetahuan (gudangpengetahuan dari domain permasalahan yang berupa data atau prosedur), dansistem pemrosesan masalah (hubungan antara 2 komponen yang berisi 1 atau lebih kapabilitas dalam memanipulasi masalah yang dibutuhkan) [8].

\subsection{Metode TOPSIS}

TOPSIS digunakan sebagai salah satu metode dalam memecahkan masalah multikriteria. TOPSIS memberikan solusi ideal positif yang relatif dan bukan solusi ideal positif yang absolut. Dalam metode TOPSIS klasik, nilai bobot dari setiap kriteria telah diketahui dengan jelas. Setiap bobot kriteria ditentukan berdasarkan tingkat kepentingannya menurut pengambil keputusan [9]. TOPSIS mempertimbangkan jarak terhadap solusi ideal positif dan jarak terhadap solusi ideal negatif secara bersamaan. Solusi optimal dalam metode TOPSIS didapat dengan menentukan kedekatan relatif suatu alternatif terhadap solusi ideal positif. TOPSIS akan merangking alternatif berdasarkan prioritas nilai kedekatan relatif suatu alternatif terhadap solusi ideal positif. Alternatif yang telah dirangking kemudian dijadikan sebagai referensi bagi pengambil keputusan untuk memilih solusi terbaik yang diinginkan [10]. Metode ini banyak digunakan untuk menyelesaikan pengambilan keputusan secara praktis. Hal ini disebabkan konsepnya sederhana dan mudah dipahami, komputasinya efisien, dan memiliki kemampuan mengukur kinerja relatif dari alternatif-alternatif keputusan. Metode TOPSIS didasarkan pada konsep bahwa alternatif terpilih yang terbaik tidakhanya memiliki jarak terpendek dari solusi ideal positif tetapi juga memiliki jarak terpanjang dari solusi ideal negatif [11].

\section{Metode Penelitian}

Tahapan metode penelitian :

1. Identifikasi Masalah

Pada tahap ini mempelajari tentang pengenalan masalah, tentang resiko penjualan online yang meliputi berbagai masalah tentang Tingkat Resiko penjualan online antara lain :Sulitnya menentukan produk yang akan di bisniskan. Sulitnya menentukan target pasar, Sulitnya menentukan strategi pemasaran.

2. Analisis Masalalah

Pada tahap ini perlu dilakukan karena penulis mengamati penelitian bahwa, dalam menganalisis tingkat Resiko penjualan online selama ini belum pernah melakukan pengukuran tingkat Resiko penjualan secara online, 
Sehingga dibutuhkanlah suatu sistem untuk menganalisis tingkat Resiko penjualan secara online

3. Pengumpulan data

Pada tahap ini merupakan aktifitas mencari atau mengumpulkan data untuk memperoleh informasi yang dibutuhkan dalam rangka mencapai tujuan penelitian seperti Observasi, studi literatur, wawancara

\section{Menerapkan Metode Topsis}

Pada tahap ini adalah menguraikan langkah-langkah dalam penyelesaian masalah secara logis dan mudah dan mengerti. Langkah-langkah tersebut, sebagai berikut :

1) .Membuat matriks keputusan yang ternormalisasi.

2) Membuat matriks keputusan yang ternormalisasi terbobot.

3) Menentukan matriks solusi ideal positif \& matriks solusi ideal negatif.

4) Menentukan jarak antara nilai setiap alternatif dengan matriks solusi ideal positif dan matriks solusi ideal negatif.

5) Menentukan nilai preferensi untuk setiap alternatif.

5. Perancangan Sistem

Sistem yang dibuat di rancang dengan menggunakan UML yang meliputi Usecase yang merupakan gambaran fungsionalitas, Activity Diagram yang merupakan alur dari sistem yang dibuat, Class Diagram yang merupakan gambaran sistem secara statis, Squence Diagramyang merupakan gambaran aksi dari sistem. Hipo Diagram digunakan untuk perancangan antarmuka. Form yang dirancang menggunakan bahasa HTML dan CSS.

6. Implementasi Sistem

Pada tahap implementasi dilakukan pembuatan sistem yang akan dirancang kedalam bahasa pemrograman dan sistem yang dihasilkan berbasis Web.

7. Pengujian Sistem

Pada tahap ini dilakukan kegiatan yang bertujuan untuk mengukur dan menilai hasil penelitian yang telah dilakukan, yaitu menguji apakah sistem yang dibuat telah layak digunaekan atau tidak. Pada pengujiannya menggunakan aplikasi berbasis web.

\section{Hasil dan Pembahasan}

Analisis data yang dipajankan dalam penelitian ini meliputi analisis data penjualan pada Ringroad Craft Medan (RRCM). Adapun data yang peroleh dari hasil penelitian yaitu data penjualan pada RRCM, data tersebut terbagi atas 3 jenis barang yaitu Mebel, Elektronik, Fashion. Dalam melakukan pengambilan keputusan, tentunya harus memiliki berbagai kriteria- kriteria yang nantinya di gunakan sebagai bahan pertimbangan dan keterkaitan dengan kasus yang akan diangkat. Kriteria kriteria yang diambil dapat menghasilkan keputusan yang baik dan tepat sehingga mendapatkan hasil yang lebih maksimal dan memuaskan serta kriteria-kriteria yang diambil relevan dengan kasus yang akan dipecahkan. Adapun kriteria - kriteria yang digunakan dalam penentuan tingkat risiko berbisnis online dengan metode TOPSIS antara lain:

1. Kriteria kualitas barang $(\mathrm{C} 1)$. Penjualan produk atau barang sangat dipengaruhi oleh kualitas produk/ barang tersebut sebab konsumen mempertimbangkan kualitas dari produk atau barang yang akan dijual sehingga tidak merasa rugi membeli produk tersebut walaupun harga dari produk tersebut mahal. Semakin tinggi variabel dari kualitas produk maka bobotnya juga semakin naik

2. Kriteria harga produk (C2). Harga produk yang dijual menentukan hasil penjualan dan target pasar yang ditentukan, sebab konsumen juga selektif dalam membandingkan harga produk yang satu dengan yang lain.

3. Kriteria Lokasi Penjual (C3)

Lokasi penjual terhadap penjualan produk mempengaruhi minta calon pembeli sebab calon pembeli mempertimbangkan biaya pengiriman dan tuntutan waktu kebutuhan pada produk yang akan dibeli. Selain itu, waktu yang di butuhkan untuk pengiriman barang cukup lama tergantung jarak antara lokasi penjual dan pembeli. Berikut 3 (tiga) sampel data penjualan online (E-Commerce) yang bisa dijalankan dan akan diuji berdasarkan kriteria yang telah ditentukan. 
Tabel 1. Data Sample

\begin{tabular}{|l|c|c|c|}
\hline \multirow{2}{*}{ Alternatif } & \multicolumn{3}{|c|}{ Bobot Kriteria } \\
\cline { 2 - 4 } & $\mathrm{C} 1$ & $\mathrm{C} 2$ & $\mathrm{X} 3$ \\
\hline Mebel & 1,00 & 0,80 & 0,40 \\
\hline Elektronik & 1,00 & 0,20 & 0,20 \\
\hline Fashion & 0,75 & 0,20 & 0,80 \\
\hline
\end{tabular}

Tabel 2. Bobot Fuzzy Setiap Kriteria

\begin{tabular}{|l|c|c|c|}
\hline \multirow{2}{*}{ Alternatif } & \multicolumn{3}{|c|}{ Bobot Kriteria } \\
\cline { 2 - 4 } & $\mathrm{C} 1$ & $\mathrm{C} 2$ & $\mathrm{X} 3$ \\
\hline Mebel & 1,00 & 0,80 & 0,40 \\
\hline Elektronik & 1,00 & 0,20 & 0,20 \\
\hline Fashion & 0,75 & 0,20 & 0,80 \\
\hline
\end{tabular}

Berdasarkan hasil perhitungan hingga X(3) dan r33, maka diperoleh matrik keputusan ternomalisasi :

$\mathrm{R}=[0,625][0,6963][0,4364]$

$[0,625][0,2357][0,2182]$

$[0,4690][0,2357][0,8728]$

Membuat matriks keputusan yang ternomalisasi terbobot $(V)$ yang elemen - elemennya ditentukan dari r (i). Perhitungan matrik keputusan ternomalisasi terbobot

$v 11=0,15 * 0,625=0,093 ; v 21=0,15$ $* 0,625=0,093 v 31=0,15 * 0,4690=0,070 ; v 12=0,20 * 0,6963=0,1392 ; v 22=0,20 * 0,2357=0,0471 ; v 32=$ $0,20 * 0,2357=0,0471 ; \quad v 13=0,20 * 0,4364=0,0872 ; \quad v 23=0,20 * 0,2182=0,0436 ; v 33=0,20 *$ $0,8728=0,1745$.

Menentukan matriks solusi ideal positif (A+) dan solusi ideal negatif $(\mathrm{A}+)$, Tabel 3 dan Tabel 4.

Tabel 3. Solusi Ideal Positif(A+)

\begin{tabular}{|c|l|l|l|}
\hline \multirow{4}{*}{$\begin{array}{l}\text { Solusi ideal } \\
\text { positif(A+) }\end{array}$} & $\mathrm{V}(\mathrm{i}, 1)$ & $\mathrm{V}(\mathrm{i}, 2)$ & $\mathrm{V}(\mathrm{i}, 3)$ \\
\cline { 2 - 4 } & 0,093 & 0,1392 & 0,0872 \\
\cline { 2 - 4 } & 0,093 & 0,0471 & 0,0436 \\
\cline { 2 - 4 } & 0,070 & 0,0471 & 0,1745 \\
\cline { 2 - 4 } & 0,093 & 0,1392 & 0,1745 \\
\hline $\mathrm{A}+(\mathrm{V} \max )$ & 0,093 & 0,1392 & 0,1745 \\
\hline
\end{tabular}

Tabel 4. Solusi Ideal Positif(A-)

\begin{tabular}{|c|c|c|c|}
\hline \multirow{5}{*}{$\begin{array}{l}\text { Solusi ideal } \\
\text { positif(A-) }\end{array}$} & $\mathrm{V}(\mathrm{i}, 1)$ & $\mathrm{V}(\mathrm{i}, 2)$ & $V(i, 3)$ \\
\hline & 0,093 & 0,1392 & 0,0872 \\
\hline & 0,093 & 0,0471 & 0,0436 \\
\hline & 0,070 & 0,0471 & 0,1745 \\
\hline & 0,093 & 0,1392 & 0,1745 \\
\hline A- $(\mathrm{V} \min )$ & 0,070 & 0,0471 & 0,0436 \\
\hline
\end{tabular}

Menghitung seperasi atau jarak alternatif dari solusi ideal positf $\left(\mathrm{S}^{+}\right), S_{I}^{+}=\sqrt{\sum_{=1}^{n}\left(v_{i j-_{j}^{+-}}^{v+}\right)}$

Menghitung seperasi atau jarak alternatif dari solusi ideal negatif $\left(\mathrm{S}^{-}\right): S_{I}^{+}=\sqrt{\sum_{=1}^{n}\left(v_{i j-_{j}^{++^{-}}}\right)}$

Dari persamaan di atas didapatkan jarak antara nilai terbobot setiap alternatif terhadap solusi ideal positif :

Tabel 5. Solusi ideal positif $\left(\mathrm{A}^{+}\right)$

\begin{tabular}{|c|c|c|c|}
\hline \multirow{3}{*}{ Solusi Ideal positif } & $\mathrm{V}(\mathrm{i}, 1)$ & $\mathrm{V}(\mathrm{i}, 2)$ & $\mathrm{V}(\mathrm{i}, 3)$ \\
\cline { 2 - 4 } & 0,093 & 0,1392 & 0,0872 \\
\cline { 2 - 4 } & 0,093 & 0,0471 & 0,0436 \\
\cline { 2 - 4 } & 0,070 & 0,0471 & 0,1745 \\
\hline $\mathrm{A}^{+}(\mathrm{V} \max )$ & 0,093 & 0,1392 & 0,1745 \\
\hline
\end{tabular}


Tabel 6. Solusi ideal positif $\left(\mathrm{A}^{--}\right)$

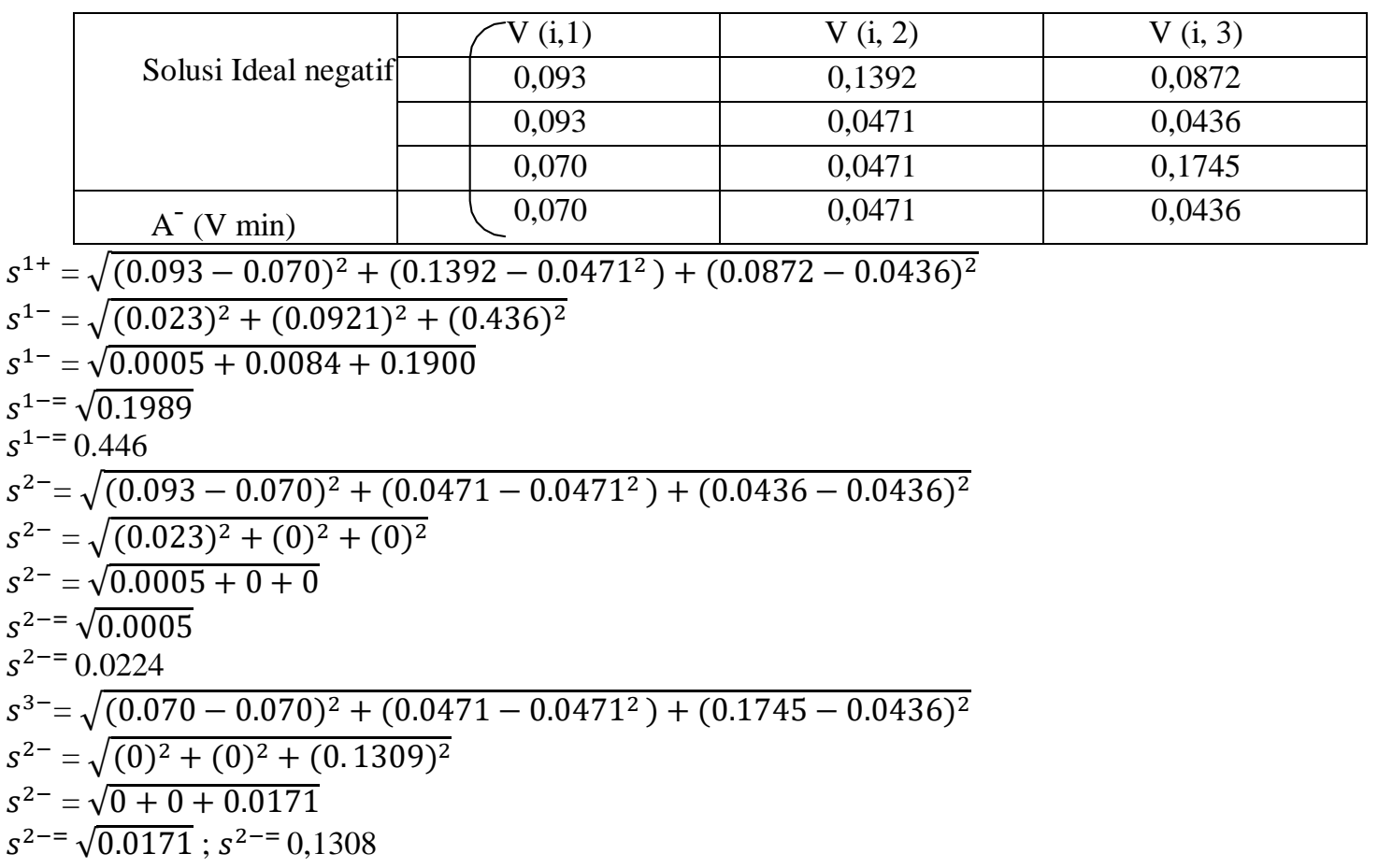

Hasil perhitungan didapat seperasi (jarak) solusi ideal positif dan jarak solusi ideal negatif seperti pada tabel 7.

Tabel 7. Nilai Seperasi (Jarak)

\begin{tabular}{|c|c|c|c|c|c|c|}
\hline Alternatif & $\mathrm{S}+$ & S- & Alternatif & $\mathrm{S}^{+}$ & $\mathrm{S}^{-}$ & $\mathrm{C}^{+}$ \\
\hline Mebel & 0,0872 & 0,446 & Mebel & 0,0872 & 0,446 & 0,8062 \\
\hline Elektronik & 0,1597 & 0,0224 & Elektronik & 0,1597 & 0,0224 & 0,1230 \\
\hline Fashion & 0,0943 & 0,1308 & Fashion & 0,0943 & 0,1308 & 0,5810 \\
\hline
\end{tabular}

Hasil perangkingan Ranking 1: Mebel =0,8062; Ranking 2 : Elektronik =0,5810; Ranking 3 Fashion =0,1230 Tampilan form-form yang dihasilkan yaitu Halaman Menu Alternatif, Halaman Menu Kriteria dan Halaman Menu Perhitungan, dapat dilihat pada Gambar 1, Gambar 2 dan Gambar 3.

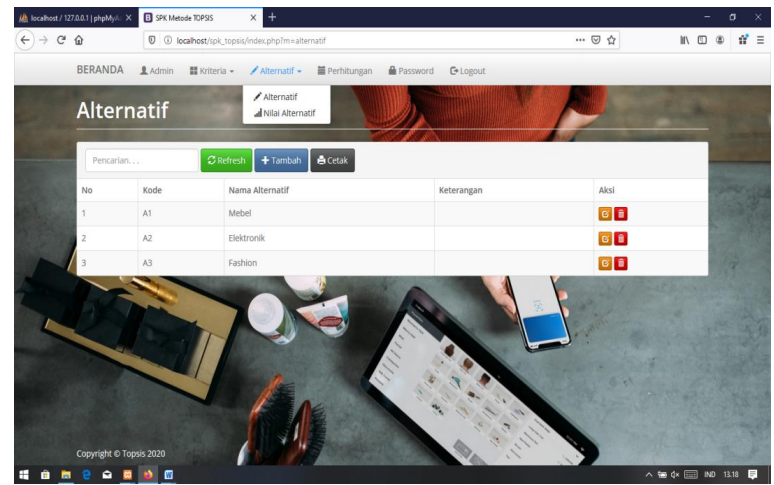

Gambar 1. Halaman Kriteria

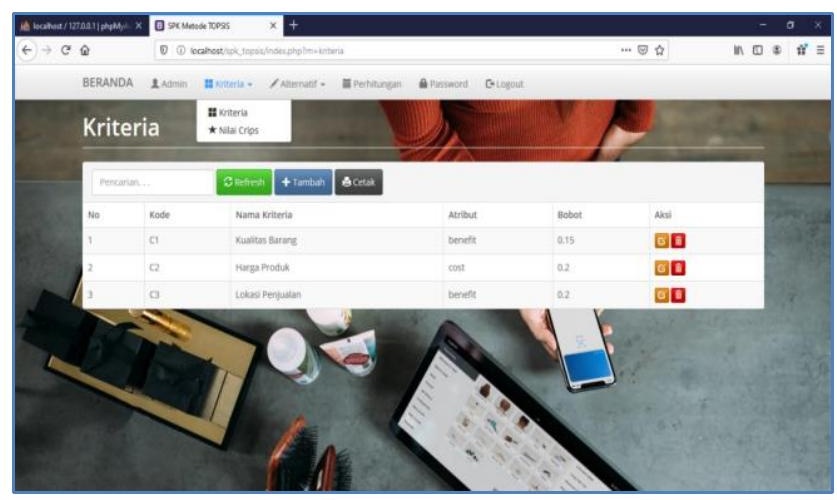

Gambar 2. Halaman Kriteria 


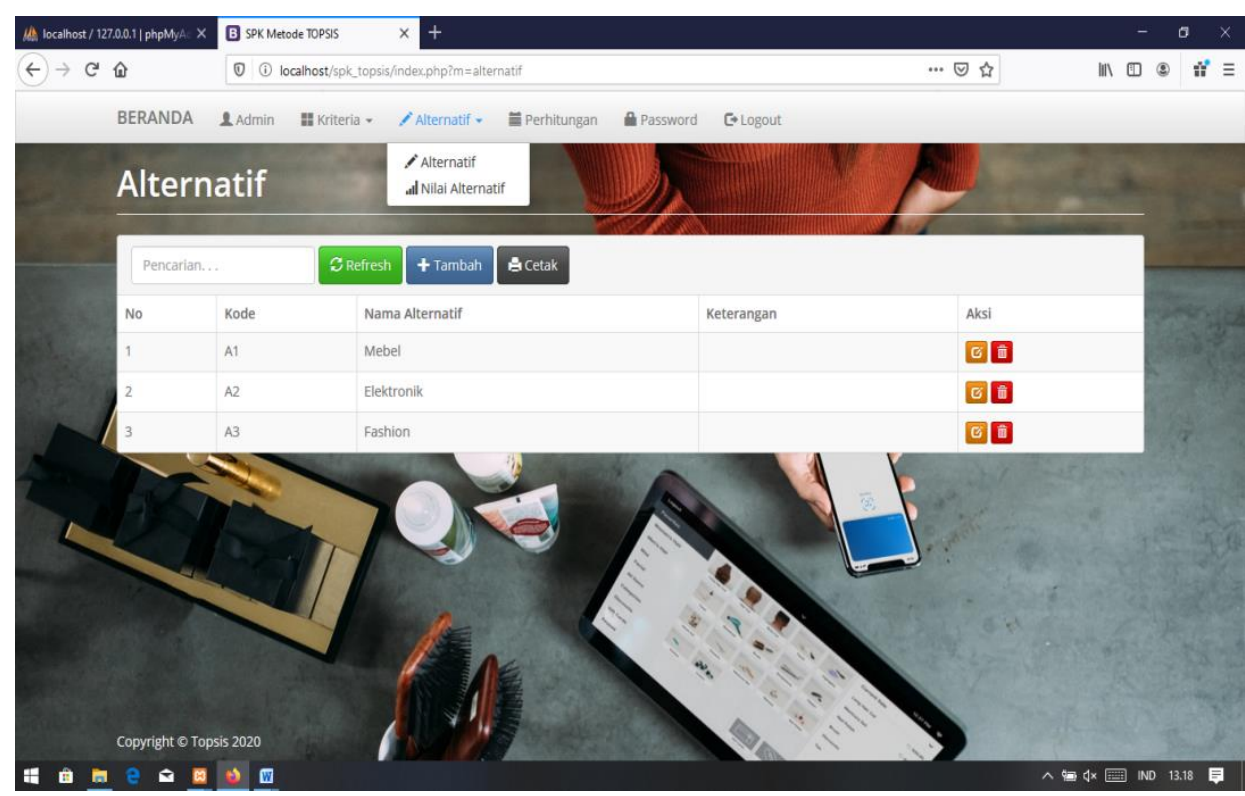

Gambar 3. Menu Perhitungan

\section{Kesimpulan}

Kesimpulan dari penelitian :

1. Penelitian ini telah mampu menghasilkan tingkat resiko barang yang dijual seperti fashion, mebel, eletronik

2. Hasil perhitungandapat dijadikan sebagai informasi yang sangat berharga dalam pengambilan keputusan untuk menentukan Tingkat Resiko penjualan Onlne yang akan dijual.

\section{Daftar Pustaka}

[1] S. Butsianto and N. T. Mayangwulan, "Penerapan Data Mining Untuk Prediksi Penjualan Mobil Menggunakan Metode K-Means Clustering," J. Nas. Komputasi dan Teknol. Inf., vol. 3, no. 3, pp. 187201, 2020.

[2] S. N. Amida and T. Kristiana, "Sistem Pendukung Keputusan Penilaian Kinerja Pegawai Dengan Menggunakan Metode Topsis," JSAI (Journal Sci. Appl. Informatics), vol. 2, no. 3, pp. 193-201, 2019.

[3] N. Chaniago and A. Sindar, "SPK Penilaian Hasil Belajar Siswa Menggunakan Metode TOPSIS," vol. 9, pp. 41-48, 2020.

[4] R. Darman, "SISTEM PENDUKUNG KEPUTUSAN PEMILIHAN IMAM SHALAT Jurnal Edik Informatika," vol. 1, pp. 1-8, 2018.

[5] M. E. Marpaung and A. S. R. Sinaga, "Penilaian Guru Terbaik SMP Tri Sakti Lubuk Pakam Menggunakan Metode Topsis," KomTekInfo, vol. 5, no. 1, pp. 28-35, 2018.

[6] P. Mauliana, N. Hunaifi, and F. Wahyudi, "Sistem Pendukung Keputusan Penerimaan Debitur Menggunakan Metode Topsis (Studi Kasus: Swamitra Ksp Intranz)," Infotronik J. Teknol. Inf. dan Elektron., vol. 3, no. 1, p. 15, 2018.

[7] I. A. Nata, B. Soedijono, H. Al, and Fatta, "Dengan Metode Topsis," Penentuan Wil. Promosi Penerimaan Siswa Baru Dengan Metod. Topsis, vol. XII, no. 34, pp. 61-80, 2017.

[8] N. D. Palasara and T. Baidawi, "Penerapan Metode Topsis Pada Peningkatan Kinerja Karyawan," $J$. Inform., vol. 5, no. 2, pp. 287-294, 2018.

[9] A. S. R. Sinaga and J. Purba, "Penentuan Karyawan Lembur Dengan Metode Analytical Hierarchy Process ( Ahp )," vol. 1, no. 2, pp. 40-50, 2018.

[10] A. Syaifullah, L. Isyriyah, and B. K. Kristanto, "Sistem Penunjang Keputusan Simulasi Penentuan Akreditasi Sekolah Dasar Menggunakan Metode Analytic Network Process (ANP) Berbasis Web (Studi Kasus Korwil Dinas Pendidikan Kecamatan Pakisaji)," J-Intech, vol. 7, no. 01, pp. 67-71, 2019.

[11] G. Wibisono, A. Amrulloh, and E. Ujianto, "Penerapan Metode Topsis Dalam Penentuan Dosen Terbaik," Ilk. J. Ilm., vol. 11, no. 2, pp. 102-109, 2019. 